\title{
Paddy Straw Management in Punjab: An Economic Analysis of Different Techniques
}

\author{
Gurinderpal Singh, Jatinder Sachdeva* and Gurjeet Singh Walia ${ }^{1}$ \\ Department of Economics and Sociology, \\ ${ }^{1}$ Department of Math, Stat and Physics, Punjab Agricultural University, Ludhiana-141 004, India \\ *E-mail: sachdeva8@pau.edu
}

\begin{abstract}
The study has been conducted to undertake economic analysis of paddy straw management in Ludhiana and Mansa districts of the Punjab state during the year 2019-20. A sample of 80 farmers growing paddy and using various methods of paddy straw management viz. insitu complete burning, partial burning and non-burning using different technologies was taken for the study. Happy seeder revealed to be the most economic approach for handling paddy straw without burning it before sowing of wheat crop. Other techniques of straw management (Straw baling technology, Straw incorporation with M B Plough and Super seeder technology) increased the burden of Rs 2000 to 5100 per hectare on the farmers. The returns from wheat crop grown using happy seeder were almost same as that of wheat grown after burning paddy straw. For wheat crop grown using other paddy straw management methods showed relatively lesser returns due to increase in variable cost. However, rodents attack, higher disease/pest incidence and expensive implements were some constraints faced by the farmers in the adoption of this technique. These issues can be addressed by using appropriate crop production strategies, short duration varieties of paddy and making these machines available to farmers on a custom-hire basis. Compensation to farmers by including the cost of paddy residue management in the MSP, ensuring the availability of residue management machines at subsidised rates, and better custom hiring services could all be the options for addressing the state's paddy straw management problems.
\end{abstract}

Keywords: Paddy straw, Economic analysis, Punjab, Straw baler, Super seeder

India has gone from a food shortage to a surplus food economy as result of green revolution. Enormous public investment decisions in modern agricultural practice and research were decided to make in the northern peninsular belt of Punjab, Haryana, and Western UP in the 1960s to substantially improve rice, wheat, and other cereal yields. Agriculture focused on high-yielding crops, chemical-based processing and protection technology, and increased food grain productivity and output, increasing farmers' income and substantially contributing to national food security. Punjab and Haryana transitioned from their traditional crops (pulses, pearl millet, maize, and oilseeds) to the rice-wheat cropping rotation in the late 1970s and early 1980s. The shift in cropping patterns was made to ensure that the country had enough food production; therefore there was no concern about resource sustainability. Punjab and Haryana now have a highly active rice-wheat region in the IGP, contributing roughly $69 \%$ of the overall food production in the country (about $84 \%$ wheat and $54 \%$ rice). Despite its significance, there have been concerns about residue production and management of rice and wheat crops. Though paddy straw burning is an issue in many states, Punjab and Haryana have the most serious cases. Since most of the farmers in Punjab were dependent on fresh groundwater for irrigation in the crops. The rice-wheat cropping rotation resulted in the overexploitation of groundwater supplies in Punjab. However, in 2009, Punjab became the first state in the country to pass a legislation prohibiting the transplantation of rice before the second fortnight of June (Punjab Preservation of Sub-Soil Water Act). The goal was to forestall the water table from declining. Most of the farmers growing long duration varieties faced the delay in the harvesting period of paddy crop by 10 to 15 days. While the regulation achieved its goal, it resulted into a short time window of merely 15 to 20 days for residue management between paddy harvesting and subsequent crop sowing. The high grain yield of paddy has also caused enormous straw production, which appears a severe problem to the farmers as its management practices are expensive and time-consuming. Around 75 to $80 \%$ of the area under paddy is machine-harvested, and approximately $95 \%$ of paddy straw is burnt annually in the state (Singh et al 2018). A study conducted at the Institute for Social and Economic Change, Bengaluru, by the Agricultural Development and Rural Transformation Centre reported that a vast cloud of smog resulted from residue burning gave rise to health hazards in rural Punjab amounting to the tune of Rs 76 million per year. Straw burning not only endangers human and animal health, but it also depletes essential nutrients like 
nitrogen, phosphorous, sulphur, and potassium from the top soil layer, making the land less productive and unsuitable for agriculture in the long term (Mandal et al 2004, Lohan et al 2018). Another study (Kumar et al 2019) examined the microbiological dynamics of soil in response to paddy straw burning. They found that after paddy straw burning, the population of significant microorganisms such as bacteria, actinomycetes, fungi, phosphate solubilizing microorganism (PSM), potassium solubilizing microorganism (KSM), and cellulose degraders was significantly reduced. Even after 60 days, the microbial population and enzyme activity involved in biomass recycling did not recover, probably due to a lack of substrates. In the long run, this could have negative consequences for soil health.

Punjab was recognized as most vibrant and progressive state for its success in green revolution. But Punjab farmers have been grappled with second-generation problems like stagnating production and profitability, excessive use of natural resources having adverse environmental effects, casting doubt on long-term viability of agriculture. As a result, the state's current primary issue is to increase crop production and profitability while successfully addressing the problem of agricultural biomass residual or crop residue burning and natural resource exploitation. Furthermore, an energy, water, and labour efficient alternative method is urgently needed to assist maintain soil and environmental quality while producing more at a lower cost (Jat et al 2011, Gathala et al 2011). Aside from the recently introduced early maturing rice varieties (PR121, PR126, and PR127), there are also other technologies available to prevent farmers from burning leftovers. The major technologies for straw management developed by the Punjab Agricultural University, Ludhiana are happy seeder, tractor operated paddy straw chopper-cum-spreader, straw collector and baler etc. These have markedly supported farmers to manage paddy residue on the farm. From the last few years, the National Green Tribunal has strictly forced the Punjab Govt. for the proper implementation of the ban with legal actions for residue burning on the farms. Keeping this in view, there is a need to evaluate the cost of residue management for these machines and the constraints faced by farmers in their use. There is also a dearth of studies on economics of paddy straw management (Singh et al 2008, Sharma et al 2016). After the imposition of ban on stubble burning by the government, it has become very important to find out economically viable alternatives of paddy straw management. As a result, the current study has been carried out to examine the economics of various paddy straw management methods used by farmers prior to seeding the wheat crop in the year 2019-20. The study also emphasised the need of evaluating and comparing the costs and benefits of various resource conservation efforts used in wheat cultivation.

\section{MATERIAL AND METHODS}

The districts of Ludhiana and Mansa were selected purposively for the study. Ludhiana district was selected due to advanced technology adoption by farmers for managing paddy straw and location of the Punjab Agricultural University. On the other hand, Mansa district was selected on account of adoption of straw baler by larger number of farmers (Sharma et al 2016). Sample of 40 farmers was selected from each selected district making a total sample of 80 farmers for the study. Primary data pertaining to the agricultural year 2019-20 were obtained on the pre-tested interview schedule by personally visiting the respondents. The straw management techniques used on the farms of selected farmers are as follows:

Zero till drill post loose straw burning: The loose straw produced with combine harvesting was burnt directly and wheat was sown in the remaining standing stubbles using 'Tractor drawn zero till drill'. No preparatory tillage is required in this practice.

Rota seeder/super seeder post loose straw burning: The loose straw produced with combine harvesting was burnt directly and wheat was sown in the remaining standing stubbles using 'Tractor operated rota seeder/super seeder'. No separate preparatory tillage is required in this practice as the seed bed preparation and sowing along with straw management is done in a single operation.

Straw baler: After harvesting of paddy using combine harvester, straw was chopped with straw cutter cum spreader. Then the rotary rake run by tractor is used to collect straw into windrows which is next turned into straw bales by 'Tractor operated straw baler'. The straw bales are then collected from the field manually and transported/stored by the farmers.

Happy seeder: After harvesting of paddy with 'Super SMS fitted Combine harvester' and wheat was sown in the standing stubbles using 'Happy seeder' run by tractor. No preparatory tillage is required in this practice.

Straw incorporation with MB plough: After harvesting of paddy, 'Tractor operated Straw mulcher/Straw cutter cum spreader' is used for chopping of paddy straw and then straw incorporated into the soil with 'Tractor mounted Mould board plough'. After incorporation various tractor drafted implements like disc harrow, cultivator, rotavator, etc. were used for the tillage. The sowing was done with seed-cumfertilizer drill.

Super seeder: After harvesting of paddy with 'Super SMS 
fitted Combine harvester' and wheat was sown in the standing stubbles using 'Super seeder' run by tractor. No separate preparatory tillage is required in this practice as the seed-bed preparation and sowing along with straw management is done in a single operation.

Burning (Control): After being cut using a straw cutter-cumspreader, the paddy straw was burnt completely, as is a common practice. The field was then sown directly with zero till drill technique or prepared by ploughing with a tractormounted disc harrow, cultivator, and other implements, and wheat was sown with a seed-cum-fertilizer drill.

The data so collected were analysed using simple statistical tools such as percentages, averages, frequency etc. However, in order to know the statistical significance of various inputs used under different paddy straw management techniques as compared to burning of paddy straw, student's t-test was employed as sophisticated statistical approach. The independent t-test, also known as the two-sample t-test, independent-samples $t$-test, or student's t-test, is an inferential statistical test that evaluates if two unrelated groups' means significantly differ statistically. The pooled variance $S^{2}$ is an unbiased estimate of common variance of the two populations. For calculating pooled variance, following formula is used:

Where,

$$
S^{2}=\frac{\left(n_{1}-1\right) s_{1}^{2}+\left(n_{2}-1\right) s_{2}^{2}}{n_{1}+n_{2}-2}
$$

$$
\begin{aligned}
& s_{1}^{2}=\frac{1}{n_{1}-1}\left(\sum x_{i}^{2}-n_{i}^{2}-n_{1} \bar{x}^{2}\right) \text { and } \\
& s_{2}^{2}=\frac{1}{n_{2}-1}\left(\sum y_{i}^{2}-n_{i}^{2}-n_{1} \bar{y}^{2}\right) \\
& \quad \bar{x}=\frac{1}{n_{1}} \sum_{i=1}^{n_{1}} x i \text { and } \bar{y}=\frac{1}{n_{2}} \sum_{j=1}^{n_{1}} y i
\end{aligned}
$$

The null hypothesis $\left(H_{0}\right)$ and alternative hypothesis $\left(H_{1}\right)$ for the independent t-test can be stated as:

$$
\begin{aligned}
& \mathrm{H}_{0}::_{1}={ }_{2} \text { or }_{1}{ }_{2}=0 \\
& \mathrm{H}_{1: 1} \neq{ }_{2} \text { or }_{1}{ }_{2} \neq 0 \text { (two tailed) } \\
& t=\frac{(\bar{x}-\bar{y})}{\sqrt{S^{2}\left(\frac{1}{n_{1}}+\frac{1}{n_{2}}\right)}} \sim t_{\alpha}=\left(n_{1}+n_{2}-2\right)
\end{aligned}
$$

If $|t| \geq t_{\alpha}\left(n_{1}+n_{2}-2\right) H_{0}$ is rejected, otherwise If $|t| \geq t_{\alpha}\left(n_{1}+\right.$ $n_{2}-2$ ), fail to reject $H_{0}$ at a level of significance.

\section{RESULTS AND DISCUSSION}

Wheat cultivation using paddy straw management practices: The input use pattern in wheat cultivation revealed that seed rate was 5 to $10 \%$ higher among no-tillage and minimum tillage techniques under straw management techniques for seed sowing as compared to the traditional method of straw burning (Table 1). The seed rate was maximum $(121.22 \mathrm{~kg} / \mathrm{ha}$ ) where crop was sown using rota seeder/super seeder followed by zero till drill, super seeder and happy seeder. Straw baler and straw incorporation with MB plough used lesser seed rate. In comparison, the seed rate used on farms using the traditional approach of straw burning was $109.05 \mathrm{~kg} / \mathrm{ha}$. Farmers' perceptions were the main reason for uneven seed rate use, as they believed that paddy straw management techniques caused germination issues, necessitating the use of higher seed rates to compensate for the poor germination problem. Use of urea was higher in straw incorporation with MB plough (366.88 $\mathrm{kg} / \mathrm{ha}$ ) and straw baler (364.54 kg/ha), while no-tillage techniques i.e., happy seeder ( $321.33 \mathrm{~kg} / \mathrm{ha})$ and zero till drill $(336.03 \mathrm{~kg} / \mathrm{ha})$ used comparatively lesser quantity of urea as compared to other techniques and minimum tillage techniques i.e., rota seeder/super seeder and super seeder showed saving in urea consumption. Application of DAP was directly related to the seed rate where no-tillage and minimum tillage resulted into higher application of DAP.

The comparison of different straw management techniques used on the sampled farms with the control, almost each method showed saving in irrigation. The irrigation hours used in happy seeder were $12 \%$ lower. This not only saves water but also energy and reduces ecological impact. Tillage is a time-consuming and expensive process (Bhatia and Dhaliwal, 2001). In machine usage, no-tillage techniques i.e., zero till drill (9.81 hrs/ha) and happy seeder (12.97 hrs/ha) showed 35 and $14 \%$ saving as compared to the control. Minimum tillage techniques i.e., rota seeder/super seeder and super seeder also showed 20 and $14 \%$ saving in machine usage. Thus, straw management with no-tillage and minimum tillage results in time saving. The use of such non-burning techniques to manage straw can have a significantly larger impact on reducing carbon emissions. The one tonne of straw is burnt, $3 \mathrm{~kg}$ of particulate matter (PM), 1.46 tonnes of $\mathrm{CO}_{2}, 60 \mathrm{~kg}$ of $\mathrm{CO}, 2 \mathrm{~kg}$ of $\mathrm{SO}_{2}$, and 0.199 tonnes of ash are released (Gupta et al 2004). Assuming an average straw yield of $9 \mathrm{t} / \mathrm{ha}$, these non-burning methods can diminish $27 \mathrm{~kg}$ of particulate matter, $540 \mathrm{~kg}$ of $\mathrm{Co}, 13.14$ tonnes of $\mathrm{CO}_{2}, 1.79$ tonnes of ash, and $18 \mathrm{~kg}$ of SO perha.

Wheat yield under various paddy straw management techniques: There was not much difference in wheat yield under various straw management techniques as compared to control. However, super seeder and straw incorporation with MB plough showed 1 to $1.5 \%$ higher yield. The other techniques showed almost same yield around the control. The analysis of variable cost structure, indicate the cost of 
machine utilisation accounted for about 40 to $50 \%$ of the total variable cost (Table 2). Tractors and equipment were used for paddy straw management, wheat crop sowing, and crop harvesting with a combine harvester; tractors were also utilized for wheat crop transportation and marketing, and then for wheat straw management. The cost of equipment usage was calculated using custom hiring rates for all of these farm operations in the study area. In absolute terms, under non-burning techniques, the highest incurred cost for the use of machinery in wheat sowing was on farms, where whole paddy straw was incorporated into the soil (Rs 17050/ha) followed by straw baler (Rs 15418/ha) and superseeder (Rs 13987/ha). The lesser expense for nonburning techniques was in Happyseeder technology (Rs $11028 / \mathrm{ha}$ ). In post loose straw burning techniques, the cost of machine labour use was Rs 9029 and Rs 10647 per ha in the case of zero till drill and rota seeder/super seeder. Therefore, compared to conventional straw burning methods, the operation of paddy straw was associated with an increase in machine costs to the tune of Rs 5067 per ha (42.28\%) for straw incorporation with MB plough, Rs 3435 per ha (28.66\%) for the straw removal with straw baler and Rs 2004 per ha $(16.72 \%)$ for straw incorporation with super seeder. But the implementation of Zero till drill, Rota seeder/super seeder and Happy Seeder technology has, in comparison with conventional practises of straw burning, reduced the machinery costs by $24.65,11.15$ and $7.97 \%$, respectively. Even though post loose straw burning techniques saved the cost of machine labour by 11 to $25 \%$ but due to ban on straw burning these techniques cannot be used for management of straw. In comparison to the control, the implementation of happy seeder, a legal non-burning method, has helped to reduce the cost of machinery by $7.97 \%$. Although only marginally, this helps to reduce emissions from fuel combustion, in addition to cost savings. The gross returns did not significantly differ among different straw management practices, with the highest (Rs 115013/ha) on farms using the straw incorporation with MB plough followed by superseeder and the lowest on farms using the happy seeder. The rest of the technologies did not show any variability in the gross returns. Returns over variable cost (ROVC) were the highest in post loose straw burning techniques adopted on farms which was Rs 88003 and Rs 86716 per ha in case of zero till drill and rota seeder/super seeder. Among the non-burning techniques, happy seeder showed almost same returns over variable cost. But the rest of the techniques i.e., straw baler, straw incorporation with $\mathrm{MB}$ plough and super seeder showed $6.16,3.76$ and $1.57 \%$ lesser returns over variable cost as compared to the control., the cost components of different technologies fluctuate, notably in terms of variable

Table 1. Input use pattern and yield of wheat crop using different paddy straw management techniques in Punjab (2019-20)

\begin{tabular}{|c|c|c|c|c|c|c|c|}
\hline \multirow[t]{3}{*}{ Particulars } & \multicolumn{6}{|c|}{ Different paddy straw management techniques } & \multirow{3}{*}{$\begin{array}{l}\text { Burning } \\
\text { (Control) }\end{array}$} \\
\hline & \multicolumn{2}{|c|}{ Loose straw burning techniques } & \multicolumn{4}{|c|}{ Non-burning techniques } & \\
\hline & ZTD & $\mathrm{RS} / \mathrm{SST}$ & SBT & HST & $\mathrm{SI}(\mathrm{MBP})$ & SST & \\
\hline Seeds $(\mathrm{Kg})$ & $\begin{array}{c}119.18^{*} \\
(3702.01)\end{array}$ & $\begin{array}{c}121.22^{* *} \\
(3822.91)\end{array}$ & $\begin{array}{l}105.61^{* *} \\
(3084.45)\end{array}$ & $\begin{array}{l}115.25^{\star *} \\
(3584.91)\end{array}$ & $\begin{array}{l}103.30^{* *} \\
(3060.00)\end{array}$ & $\begin{array}{c}116.30^{*} \\
(3766.32)\end{array}$ & $\begin{array}{c}109.05 \\
(3211.17)\end{array}$ \\
\hline Urea $(\mathrm{Kg})$ & $\begin{array}{c}336.03^{*} \\
(1989.20)\end{array}$ & $\begin{array}{c}352.57 \\
(2087.42)\end{array}$ & $\begin{array}{l}364.54^{\star *} \\
(2157.70)\end{array}$ & $\begin{array}{c}321.33^{*} \\
(1902.44)\end{array}$ & $\begin{array}{l}366.88^{* *} \\
(2171.67)\end{array}$ & $\begin{array}{c}352.08 \\
(2084.40)\end{array}$ & $\begin{array}{c}357.04 \\
(2113.69)\end{array}$ \\
\hline DAP $(\mathrm{Kg})$ & $\begin{array}{c}137.80^{*} \\
(3307.08)\end{array}$ & $\begin{array}{c}134.23 \\
(3221.84)\end{array}$ & $\begin{array}{c}130.61 \\
(3134.66)\end{array}$ & $\begin{array}{c}135.70 \\
(3256.98)\end{array}$ & $\begin{array}{c}130.13 \\
(3123.12)\end{array}$ & $\begin{array}{c}134.96 \\
(3239.06)\end{array}$ & $\begin{array}{c}132.51 \\
(3180.14)\end{array}$ \\
\hline Other fertilizers (Rs) & $\begin{array}{c}- \\
(205.06)\end{array}$ & (335.53) & $(232.82)$ & (185.84) & $(108.18)$ & (134.39) & (133.04) \\
\hline Irrigation (Hrs) & $\begin{array}{c}26.11 \\
(286.02)\end{array}$ & $\begin{array}{c}27.19 \\
(172.45)\end{array}$ & $\begin{array}{c}27.10 \\
(244.26)\end{array}$ & $\begin{array}{c}24.59 \\
(213.82)\end{array}$ & $\begin{array}{c}26.35 \\
(162.05)\end{array}$ & $\begin{array}{c}26.32 \\
(328.23)\end{array}$ & $\begin{array}{c}27.57 \\
(204.07)\end{array}$ \\
\hline Plant protection & $\begin{array}{c}- \\
\text { (2983.09) }\end{array}$ & $\begin{array}{c}- \\
(3047.05)\end{array}$ & $\begin{array}{c}- \\
(3073.30)\end{array}$ & $\begin{array}{c}- \\
(3271.74)\end{array}$ & $\stackrel{-}{(3162.14)}$ & $\begin{array}{c}- \\
(3244.82)\end{array}$ & $\begin{array}{c}- \\
(2899.61)\end{array}$ \\
\hline Human Labour (Hrs) & $\begin{array}{c}63.07^{*} \\
(2838.12)\end{array}$ & $\begin{array}{c}67.63 \\
(3087.96)\end{array}$ & $\begin{array}{c}104.85^{\star} \\
(4872.20)\end{array}$ & $\begin{array}{c}60.36^{*} \\
(2817.47)\end{array}$ & $\begin{array}{c}69.48 \\
(3277.31)\end{array}$ & $\begin{array}{c}65.34^{*} \\
(3022.13)\end{array}$ & $\begin{array}{c}69.42 \\
(3246.23)\end{array}$ \\
\hline Machine Labour (Hrs) & $\begin{array}{c}9.81^{*} \\
(9029.23)\end{array}$ & $\begin{array}{c}12.11^{*} \\
(10646.54)\end{array}$ & $\begin{array}{c}21.77^{\star} \\
(15418.06)\end{array}$ & $\begin{array}{c}12.97^{\star} \\
(11028.31)\end{array}$ & $\begin{array}{c}16.16 \\
(17050.02)\end{array}$ & $\begin{array}{c}13.08^{*} \\
(13986.94)\end{array}$ & $\begin{array}{c}15.15 \\
(11983.19)\end{array}$ \\
\hline Yield (Kg) & $\begin{array}{c}5227 \\
(100619.75)\end{array}$ & $\begin{array}{c}5258 \\
(101216.50)\end{array}$ & $\begin{array}{c}5233 \\
(100735.25)\end{array}$ & $\begin{array}{c}5199 \\
(100080.75)\end{array}$ & $\begin{array}{c}5290 \\
(101832.50)\end{array}$ & $\begin{array}{c}5290 \\
(101832.50)\end{array}$ & $\begin{array}{c}5220 \\
(100485.00)\end{array}$ \\
\hline
\end{tabular}

Figures in the parenthesis represents the value in rupees

ZTD- Zero Till Drill, RS/SST- Roto Seeder/Super Seeder Technology, SBT- Straw Baling Technology, HST- Happy Seeder Technology, SI (MBP)- Straw Incorporation (Mould Board Plough), SST- Super Seeder Technology

Independent sample t-test ( ${ }^{*}$ and ${ }^{* *}$ denote the difference between various inputs used in different straw management techniques and control significant at $1 \%$ and $5 \%$ level of significance) 
cost on paddy straw removal and incorporation, resulting in varied returns over variable cost in wheat cultivation under different straw management techniques.

Problems faced in paddy straw management: The constraints faced by farmers in the adoption of various paddy straw management techniques have been classified into three categories namely management constraints, postmanagement constraints and economic constraints (Table $3)$. In the case of management constraints, farmers adopting different technologies for straw management instead of burning it in the field (non-burning method) were facing more problems as compared to farmers adopting partial burning method of paddy straw management. Shortage of skilled labour was the major problem faced by all the farmers adopting MB plough for straw management. The corresponding figures for farmers adopting happy seeder technology, super seeder technology and straw baling technology were $77.78,75$ and $40 \%$, respectively. Delayed sowing of proceeding crop was reported by 62.5 and $15 \%$ of the farmers adopting MB plough and straw baling technology, respectively. Moreover, shortage of hired machinery was another problem faced by 50 and $35 \%$ of the farmers adopting straw baling and super seeder technology, respectively. In case of partial burning, $100 \%$ farmers who adopted rota seeder /super seeder technology after burning of paddy loose straw felt the need of skilled labour for proper sowing of proceeding crop and management of standing stubbles. The $37.5 \%$ of the respondents who adopted zero tillage technology also reported the same problem. Further, $50 \%$ of the farmers adopting rota seeder /super seeder technology reported the shortage of hired machinery for the adoption.

In post-management constraints, $75 \%$ of the farmers adopting zero tillage technology after partial burning reported the difficulty in intercultural operation as a major problem in the adoption. The problem of difficulty in sowing of

Table 2. Cost-return structure of wheat cultivation under different methods of paddy straw management in Punjab (2019-20)

\begin{tabular}{|c|c|c|c|c|c|c|c|}
\hline \multirow[t]{3}{*}{ Particulars } & \multicolumn{6}{|c|}{ Different paddy straw management techniques } & \multirow{3}{*}{$\begin{array}{l}\text { Burning } \\
\text { (Control) }\end{array}$} \\
\hline & \multicolumn{2}{|c|}{$\begin{array}{l}\text { Post loose straw burning } \\
\text { techniques }\end{array}$} & \multicolumn{4}{|c|}{ Non-burning techniques } & \\
\hline & ZTD & RS/SST & SBT & HST & $\mathrm{SI}(\mathrm{MBP})$ & SST & \\
\hline Cost of human Labour & $\begin{array}{c}2838 \\
(11.40)\end{array}$ & $\begin{array}{c}3088 \\
(11.43)\end{array}$ & $\begin{array}{c}4872 \\
(14.79)\end{array}$ & $\begin{array}{c}2817 \\
(10.49)\end{array}$ & $\begin{array}{l}3277 \\
(9.98)\end{array}$ & $\begin{array}{l}3022 \\
(9.92)\end{array}$ & $\begin{array}{c}3246 \\
(11.77)\end{array}$ \\
\hline Cost of machine Labour & $\begin{array}{c}9029 \\
(36.28)\end{array}$ & $\begin{array}{c}10647 \\
(39.41)\end{array}$ & $\begin{array}{l}15418 \\
(46.80)\end{array}$ & $\begin{array}{c}11028 \\
(41.07)\end{array}$ & $\begin{array}{l}17050 \\
(51.92)\end{array}$ & $\begin{array}{l}13987 \\
(45.89)\end{array}$ & $\begin{array}{c}11983 \\
(43.45)\end{array}$ \\
\hline Cost of seeds & $\begin{array}{c}3702 \\
(14.88)\end{array}$ & $\begin{array}{c}3823 \\
(14.15)\end{array}$ & $\begin{array}{l}3084 \\
(9.36)\end{array}$ & $\begin{array}{c}3585 \\
(13.35)\end{array}$ & $\begin{array}{l}3060 \\
(9.32)\end{array}$ & $\begin{array}{c}3766 \\
(12.36)\end{array}$ & $\begin{array}{c}3211 \\
(11.64)\end{array}$ \\
\hline Cost of fertilizers & $\begin{array}{c}5501 \\
(22.10)\end{array}$ & $\begin{array}{c}5645 \\
(20.90)\end{array}$ & $\begin{array}{l}5526 \\
(16.77)\end{array}$ & $\begin{array}{c}5345 \\
(19.91)\end{array}$ & $\begin{array}{l}5403 \\
(16.45)\end{array}$ & $\begin{array}{c}5457 \\
(17.91)\end{array}$ & $\begin{array}{c}5427 \\
(19.68)\end{array}$ \\
\hline Cost of plant protection & $\begin{array}{c}2983 \\
(11.99)\end{array}$ & $\begin{array}{c}3047 \\
(11.28)\end{array}$ & $\begin{array}{l}3073 \\
(9.33)\end{array}$ & $\begin{array}{c}3272 \\
(12.19)\end{array}$ & $\begin{array}{l}3162 \\
(9.63)\end{array}$ & $\begin{array}{c}3245 \\
(10.65)\end{array}$ & $\begin{array}{c}2900 \\
(10.52)\end{array}$ \\
\hline Cost of irrigation & $\begin{array}{c}286 \\
(1.15)\end{array}$ & $\begin{array}{c}172 \\
(0.64)\end{array}$ & $\begin{array}{c}244 \\
(0.74)\end{array}$ & $\begin{array}{c}214 \\
(0.80)\end{array}$ & $\begin{array}{c}162 \\
(0.49)\end{array}$ & $\begin{array}{c}328 \\
(1.08)\end{array}$ & $\begin{array}{c}204 \\
(0.74)\end{array}$ \\
\hline $\begin{array}{l}\text { Interest @ } 9 \text { pa for half season } \\
\text { of wheat crop }\end{array}$ & $\begin{array}{c}548 \\
(2.20)\end{array}$ & $\begin{array}{c}594 \\
(2.20)\end{array}$ & $\begin{array}{c}725 \\
(2.20)\end{array}$ & $\begin{array}{c}591 \\
(2.20)\end{array}$ & $\begin{array}{c}723 \\
(2.20)\end{array}$ & $\begin{array}{c}671 \\
(2.20)\end{array}$ & $\begin{array}{c}607 \\
(2.20)\end{array}$ \\
\hline Total variable cost & $\begin{array}{c}24887 \\
(100.00)\end{array}$ & $\begin{array}{c}27016 \\
(100.00)\end{array}$ & $\begin{array}{c}32942 \\
(100.00)\end{array}$ & $\begin{array}{c}26852 \\
(100.00)\end{array}$ & $\begin{array}{c}32837 \\
(100.00)\end{array}$ & $\begin{array}{c}30477 \\
(100.00)\end{array}$ & $\begin{array}{c}27578 \\
(100.00)\end{array}$ \\
\hline Value of main product & 100620 & 101217 & 100735 & 100081 & 101833 & 101833 & 100485 \\
\hline Value of By-product & 12270 & 12515 & 12333 & 12301 & 13181 & 12690 & 12477 \\
\hline Gross return & 112890 & 113732 & 113068 & 112382 & 115013 & 114522 & 112962 \\
\hline ROVC & 88003 & 86716 & 80126 & 85530 & 82176 & 84045 & 85384 \\
\hline $\begin{array}{l}\text { Percentage difference of ROVC } \\
\text { in comparison to Control }\end{array}$ & 3.07 & 1.56 & -6.16 & 0.17 & -3.76 & -1.57 & - \\
\hline I-O Ratio & 4.54 & 4.21 & 3.43 & 4.19 & 3.5 & 3.76 & 4.1 \\
\hline $\begin{array}{l}\text { Percentage difference of I-O } \\
\text { Ratio in comparison to Control }\end{array}$ & 10.74 & 2.78 & -16.21 & 2.17 & -14.49 & -8.26 & - \\
\hline
\end{tabular}


proceeding crop and rodent attack was informed by $50 \%$ of the farmers adopting this method. Around $25 \%$ farmers pointed out the risk of higher disease or pest incidence in this method. In the case of non-burning method, $77.78 \%$ of the farmers adopting happy seeder technology were facing rodent attack as the major problem. Higher disease or pest incidence and difficulty in sowing of proceeding crop was also faced by $44.44 \%$ of the farmers adopting this method. $37.5 \%$ of the farmers adopting MB plough pointed to the abovementioned problem. Higher weed infestation was faced by $41.67 \%$ farmers adopting super seeder technology for paddy straw management. In economic constraints, majority of the farmers adopting partial burning method with zero till drill (87.5\%) and rota seeder/super seeder technology (100\%) complained about high cost of implements used for paddy straw management. All the farmers who adopted rotaseeder/superseeder and $75 \%$ of the farmers adopting zero till drill technology were worried about no market value of paddy straw. Further, 50\% farmers who adopted rota seeder/super seeder technology were worried for high hiring charges of machinery. All the farmers adopting non-burning method observed that expensive implements were the major constraint for adoption of paddy straw management techniques. In addition to that 75 and $62.5 \%$ farmers adopting straw baler and MB plough for straw management were concerned about extra cost involved in paddy straw management. Around 66.67 and $45 \%$ farmers adopting super seeder and straw baler technology were facing problem of high hiring charges of machinery. Some farmers also reported no market value of paddy straw and delay in subsidy process as constraints in adoption of non-burning technologies of paddy straw management.

In order to resolve the constraints of paddy straw management, possible steps need to be undertaken. Farmers should use short duration varieties of paddy crop to widen the time window between harvesting of paddy crop and sowing of wheat crop. Selection of the straw management implements should be according to the availability of time. Government may focus on providing more field trainings, method demonstrations and extension contacts for the farmers to tackle the problem of lack of skilled labour and teach them about economic potential of paddy straw. Farmers' organizations at the village, district and state levels may also be developed and strengthened in order to promote location-specific paddy straw management. There is a need to promote custom-hiring services by co-operative societies, co-farmers, and other private organizations, so that small and marginal farmers can implement it quickly and economically. Compensating the farmers for not burning the rice residual in fields would result into additional income to farmers and at the same time reduces local pollution effects from straw burning.

Table 3. Various constraints reported by sampled farmers in the adoption of various paddy straw management techniques (\%)

\begin{tabular}{|c|c|c|c|c|c|c|}
\hline \multirow[t]{2}{*}{ Particulars } & \multicolumn{2}{|c|}{ Post loose straw burning } & \multicolumn{4}{|c|}{ Non-burning techniques } \\
\hline & ZTD & $\mathrm{RS} / \mathrm{SST}$ & SBT & HST & $\mathrm{SI}(\mathrm{MBP})$ & SST \\
\hline \multicolumn{7}{|l|}{ Management constraints } \\
\hline It delays sowing of proceeding crop & 0.00 & 0.00 & 15.00 & 0.00 & 62.50 & 0.00 \\
\hline Shortage of skilled labour & 37.50 & 100.00 & 40.00 & 77.78 & 100.00 & 75.00 \\
\hline Shortage of hired machinery & 0.00 & 50.00 & 35.00 & 0.00 & 0.00 & 50.00 \\
\hline \multicolumn{7}{|l|}{ Post-management constraints } \\
\hline Difficulty in sowing & 50.00 & 0.00 & 0.00 & 44.44 & 37.50 & 25.00 \\
\hline Difficulty in intercultural operation & 75.00 & 0.00 & 0.00 & 22.22 & 0.00 & 0.00 \\
\hline Poor seed germination & 0.00 & 0.00 & 0.00 & 33.33 & 0.00 & 8.33 \\
\hline Higher weed infestation & 0.00 & 0.00 & 0.00 & 33.33 & 0.00 & 41.67 \\
\hline Rodent attack & 50.00 & 0.00 & 0.00 & 77.78 & 12.50 & 16.67 \\
\hline Decreased yield of the proceeding crop & 0.00 & 0.00 & 0.00 & 22.22 & 37.50 & 0.00 \\
\hline Higher disease/ pest incidence & 25.00 & 0.00 & 0.00 & 44.44 & 0.00 & 0.00 \\
\hline \multicolumn{7}{|l|}{ Economic constraints } \\
\hline Extra cost involved in paddy straw management & 0.00 & 0.00 & 75.00 & 0.00 & 62.50 & 33.33 \\
\hline High hiring charges of machinery & 0.00 & 50.00 & 45.00 & 0.00 & 0.00 & 66.67 \\
\hline No market value for paddy straw & 75.00 & 100.00 & 50.00 & 33.33 & 62.50 & 75.00 \\
\hline Delay in the subsidy process & 25.00 & 0.00 & 0.00 & 0.00 & 12.50 & 25.00 \\
\hline Implements are expensive & 87.50 & 100.00 & 100.00 & 100.00 & 100.00 & 100.00 \\
\hline
\end{tabular}




\section{CONCLUSIONS}

Straw baler, super seeder and straw incorporation with MB plough before wheat sowing, impose an economic strain on farmers to the range of Rs 2000 to Rs 5100 per ha. Straw incorporation with $\mathrm{MB}$ plough also delayed the wheat sowing since the soil took more time to reach the proper seed bed for sowing. Although Happy seeder is quite economical, but wheat crop sown using this method faced attack of pink stem borer and rodents. Some regulatory measures exist, such as impediments for paddy straw burning, and availability of subsidies on straw management implements but also paying farmers for ecosystem services is the need of the hour. Compensation for farmers by including the cost of paddy residue management in the MSP, ensuring the availability of residue management machines at subsidised rates, better custom hiring services and promoting the use of paddy straw in paper mills, energy generation plants, and other industries could all be options for addressing the state's paddy straw management problem.

\section{REFERENCES}

Bhatia BS and Dhaliwal IS 2001. Strip tillage: For sowing wheat without tillage. Conservation Agriculture-Status and Prospects PAU, Ludhiana 40(4): 280-90.

Gathala M, Ladha JK, Balyan V, Saharawat YS, Kumar V and Sharma PK 2011. Effect of tillage and crop establishment methods on physical properties of a medium-textured soil under 7-year rice-wheat rotation. Soil Science Society of America Journal 75(5): 1851-1862.

Government of India 2018. Kharif Market Season (KMS) Procurement of Rice 2018-19. Ministry of Agriculture and

Received 13 October, 2021; Accepted 28 December, 2021
Farmers' Welfare, New Delhi.

Gupta PK, Sahai S, Singh N, Dixit CK, Singh DP and Sharma C 2004. Residue burning in rice-wheat cropping system: Causes and implications. Current Science 87(12): 1713-1715.

Jat ML, Saharawat YS and Gupta R 2011. Conservation Agriculture in Cereal Systems of South Asia: Nutrient Management Perspectives. Karnataka Journal of Agricultural Sciences 24(1): 100-105.

Kaur B, Sidhu RS and Vatta K 2010. Optimal crop plans for sustainable water use in Punjab. Agricultural Economics Research Review 23(2): 273-84.

Kumar A, Kushwaha KK, Singh S, Shivay YS, Meena MC and Nain L 2019. Effect of paddy straw burning on soil microbial dynamics in sandy loam soil of Indo-Gangetic plains. Environmental Technology \& Innovation 16: 1-10.

Lohan SK, Jat HS, Yadav AK, Sidhu HS, Jat ML, Choudhary M, Peter JK and Sharma PC 2018. Burning issues of paddy residue management in north-west states of India. Renewable and Sustainable Energy Reviews 81(1): 693-706.

Mandal KG, Misra AK, Hati KM, Bandyopadhyay KK, Ghosh PK and Mohanty M 2004. Rice residue- management options and effects on soil properties and crop productivity. Journal of Food, Agriculture and Environment 2(1): 224-231.

Sharma A and Chandel R 2016. Comparative field and economic evaluation of baler for baling paddy straw. Agricultural Engineering 3: 69-76.

Singh R, Mahajan G, Kaur S and Chauhan BS 2018. Issues and strategies for rice residue management to unravel winter smog in North India. Current Science 114(12): 2419.

Singh Y and Sidhu HS 2014. Management of cereal crop residues for sustainable rice-wheat production system in the Indo-Gangetic plains of India. Proceedings of the Indian National Science Academy 80(1): 95-114.

Singh RP, Dhaliwal HS, Humphreys E, Sidhu HS, Singh M, Singh Y and Blackwell $\mathrm{J}$ 2008. Economic assessment of the Happy Seeder for rice-wheat systems in Punjab, India. Proceedings of Australian Agricultural and Resource Economics Society 52nd Annual conference, February 5-8, Canberra, ACT, Australia. 